\title{
PENGARUH SUBSTITUSI TEPUNG IKAN LELE TERHADAP PEMBUATAN COOKIES BEBAS GLUTEN DAN KASEIN SEBAGAI ALTERNATIF JAJANAN ANAK AUTISM SPECTRUM DISORDER
}

\author{
Effect of Catfish Flour Substitution towards Gluten-Free and Casein-Free Cookies as an \\ Alternative Snack for Children with Autism Spectrum Disorder
}

\author{
Aliffah Nurria Nastiti ${ }^{*}$, Juliana Christyaningsih ${ }^{2}$ \\ ${ }^{1}$ Program Studi S1 Ilmu Gizi, Fakultas Kesehatan Masyarakat, Universitas Airlangga, Surabaya, Indonesia \\ ${ }^{2}$ Politeknik Kesehatan Kementerian Kesehatan Surabaya, Indonesia \\ E-mail: aliffahnurria@gmail.com
}

\begin{abstract}
ABSTRAK
Anak dengan Autism Spectrum Disorder (ASD) memiliki kondisi gangguan pencernaan, sehingga diet pada anak dengan ASD adalah diet bebas gluten dan bebas kasein. Produk makanan bebas gluten dan kasein cenderung rendah protein. Anak ASD dengan diet bebas gluten dan kasein memiliki asupan kalsium yang lebih rendah dan kepadatan tulang yang kurang. Tepung ikan lele dengan kandungan protein dan kalsium yang tinggi diharapkan mampu meningkatkan nilai gizi (protein dan kalsium) cookies bebas gluten dan kasein. Penelitian ini bertujuan untuk mengetahui pengaruh substitusi tepung ikan lele terhadap daya terima dan nilai gizi cookies bebas gluten dan kasein. Penelitian ini merupakan eksperimen murni dengan rancangan percobaan Rancangan Acak Lengkap. Panelis pada penelitian ini meliputi anak ASD (4-6 tahun) dan orang tua, sebanyak 40 orang. Terdapat 4 formula pada studi ini. F0 sebagai kontrol, dan 3 formula yang disubstitusi. Persentase substitusi tepung badan dan tepung tulang ikan lele yaitu, F2 (2\%:2\%); F3 (4\%:4\%); dan F5 (6\%:4\%). Hasil uji Kruskal Wallis menunjukkan ada perbedaan pada tingkat kesukaan yang signifikan pada aspek rasa dan aroma antar F0, F3, dan F5. Dari hasil daya terima dan nilai gizi didapatkan hasil formula terbaik adalah F5. Dalam 100 gram cookies F5 (protein: 6,8 g; kalsium: 247,5 mg) dapat memenuhi 19\% kecukupan protein dan 24,8\% kecukupan kalsium untuk anak usia 4-6 tahun. Cookies bebas gluten dan bebas kasein substitusi tepung ikan lele pada Formula 5 layak sebagai jajanan tinggi kalsium dan cukup protein sebagai alternatif jajanan anak ASD.
\end{abstract}

Kata kunci: bebas gluten, bebas kasein, tepung ikan lele, cookies, kalsium

\begin{abstract}
Children with Autism Spectrum Disorder (ASD) have digestive disorders, therefore their diet should be gluten-free and casein-free. Gluten-free and casein-free foods tend to be low in protein. ASD children who apply a gluten-free diet and casein have a lower calcium intake and low in bone density. Catfish flour with high protein and calcium content were expected to increase the nutritional value (protein and calcium) of cookies which gluten-free and casein-free. This study was aimed to determine the effect of catfish flour substitution towards acceptance and nutritional value of gluten and casein free cookies as an alternative snack for ASD children. This study was experimental research with Completely Randomized Design. Panelists of this study were children with ASD (4-6 years) and their parents as many as 40 people. There were 4 formulas in this study, FO was control, and 3 substitution formulas. Percentage of Flour substitution were, F2 (2\%: 2\%); F3 (4\%: 4\%); and F5 (6\%: 4\%). Kruskal Wallis test showed no significant difference in the level on acceptance level in taste and aroma between FO, F3, and F5. The acceptability and nutritional value's ranking showed the best formula was F5. 100 grams of F5 cookies (protein: $6.75 \mathrm{~g}$; calcium: $247.51 \mathrm{mg}$ ) can fulfill $19 \%$ of the protein and $24.8 \%$ calcium of children RDA (4-6 years). Gluten-free and casein-free cookies with catfish (Formula 5) with enough protein and high calcium can be an alternative snack for ASD children.
\end{abstract}

Keywords: gluten free, casein free, catfish flour, cookies, calcium

C2019. The formal legal provisions for access to digital articles of this electronic journal are subject to the terms of the Creative Commons Attribution-NonCommercial-ShareAlike license (CC BY-NC-SA 4.0). Received 26-09-2017, Accepted 12-01-2018, Published online 31-01-2019 


\section{PENDAHULUAN}

Jumlah penyandang Autism Spectrum Disorder (ASD) semakin meningkat setiap tahunnya Center for Disease Control (CDC) Amerika Serikat pada 2012 menyebutkan bahwa 1 dari 68 anak menderita ASD (CDC, 2014). Departemen Kesehatan Indonesia (2012) mencatat jumlah penyandang ASD mencapai 150-200 ribu orang.

Anak-anak dengan ASD mengalami masalah pencernaan yaitu, meningkatnya permeabilitas gastro-intestinal, sehingga penyerapan produk sampingan dari protein tidak lengkap dicerna (seperti kasein dari susu dan gluten dari gandum). (Mulloy et al., 2009). Postorino, et al (2015), menyebutkan bahwa kelompok anak penyandang ASD dengan diet Casein-free and Gluten-free (CFGF) secara signifikan mengurangi tanda dan gejala ASD.

Survey pasar yang telah dilakukan oleh peneliti, menemukan bahwa $>50 \%$ produk makanan yang dijual merupakan makanan berbahan dasar tepung terigu (mie instan, biskuit, aneka makanan ringan, roti, pastri, dll). Pilihan bahan makanan yang mendukung diet CFGF sangat minim sekali. Hasil penelitian Megawati (2011) mengenai pola makan anak ASD menunjukan bahwa, 72,3\% anak dengan autis masih mengonsumsi makanan sumber gluten, yaitu biskuit.

Jajanan anak bebas gluten dan bebas kasein cenderung memiliki nilai gizi protein yang kurang. Peningkatan nilai gizi protein pada bahan makanan bebas gluten dan kasein perlu dilakukan untuk mempertahankan kecukupan protein pada anak ASD, sehingga dengan menerapkan diet Casein Free dan Gluten Free (CFGF) kebutuhan zat gizi harian tetap terpenuhi.

Gambaran asupan kalsium pada anak dengan ASD pada salah satu yayasan di Kota Surabaya hanya mencapai $50 \%$ dari kecukupan sehari (Megawati, 2011). Kalsium penting untuk pertumbuhan dan mineralisasi tulang dan gigi. Peak Bone Mass (PBM) merupakan fase yang terjadi pada usia anak-anak dan remaja hingga usia 18-20 tahun. Faktor-faktor yang mempengaruhi PBM antara lain genetik, asupan kalsium, aktivitas fisik dan asupan vitamin D (Amalia dan Dieny, 2014; Truswell dan Mann, 2012). Asupan kalsium yang rendah dapat memperlambat laju pertumbuhan.

Ekhlaspour (2016), menyebutkan bahwa anak dengan ASD memiliki kepadatan tulang yang lebih rendah dibandingkan dengan anak normal. Kepadatan tulang yang rendah ini berada pada tulang bagian lumbar spine, femoral neck, dan hip. Neumeyer (2015) menyebutkan bahwa kepadatan tulang yang rendah pada anak autis erat kaitannya dengan rendahnya asupan kalsium. Bahan makanan utama sumber kalsium adalah susu dan hasil olahannya. Susu memiliki ketersediaan biologis tinggi kalsium, sebab disertai dengan laktosa yang dapat meningkatkan absorbsi kalsium (Lean, 2013). Sangat tidak dianjurkan anak dengan ASD konsumsi susu dan produk olahan susu terkait dengan adanya perbedaan metabolisme kasein, sehingga perlu adanya alternatif bahan makanan lain yang dapat meningkatkan asupan kalsium.

Penelitian Megawati

(2011) menyebutkan bahwa, cookies merupakan 
jajanan paling disukai anak dengan ASD dikarenakan harga yang terjangkau, akses yang mudah, nilai gizi yang bagus dan mutu organoleptik yang disukai anak-anak, disisi lain cookies merupakan makanan sumber gluten dan kasein. Hal ini dikarenakan bahan baku cookies komersial adalah terigu dan susu, diamana terigu merupakan sumber gluten dan susu merupakan sumber kasein (Faridah et al., 2008).

Sumber asam amino yang baik dan disertai dengan nilai mutu cerna protein yang baik berasal dari bahan pangan hewani. Bahan pangan hewani yang seminimal mungkin untuk memicu alergi pada anak autis adalah ikan air tawar. Kombinasi protein nabati dan hewani akan mempengaruhi peningkatan mutu protein, yang mana kedua jenis protein tersebut dapat saling melengkapi kandungan asam amino dari masing-masing jenis bahan (Tejasari, 2005).

Ikan Lele merupakan ikan air tawar yang banyak dibudidaya sehingga ketersediaannya cukup stabil. Ikan Lele sering menjadi pilihan dalam penganekaragaman bahan makanan dikarenakan kandungan asam amino yang lengkap dan harga yang terjangkau. Kandungan gizi tepung badan ikan lele per 100 gram adalah energi $413 \mathrm{kkal}$, lemak $9 \mathrm{~g}$, protein $56 \mathrm{~g}$, karbohidrat $27 \mathrm{~g}$.

Salah satu diversifikasi bahan pangan pada ikan lele ini adalah pembuatan tepung ikan. Makanan dengan bahan tepung tapioka, tepung beras, dan tepung maizena seringkali digunakan untuk membuat cookies bebas gluten dan kasein. Tepung kepala ikan lele memiliki kandungan kalsium yang tinggi, yakni 4x kalsium dari susu skim. Susu skim merupakan tepung susu yang digunakan dalam pembuatan cookies (Faridah, 2008). Kandungan kalsium pada tepung susu skim yakni 1300mg/100 g bahan (Persagi, 2009).

Tepung badan ikan lele mengandung lebih tinggi energi, lemak, karbohidrat dan protein dibandingkan tepung kepala ikan lele. Namun kandungan kalsium dan fosfor lebih tinggi pada tepung kepala ikan lele dibandingkan badannya. Tepung badan ikan lele per 100 gr mengandung energi $413 \mathrm{kkal}$, lemak 9 gr, protein 5 gr, karbohidrat 27 gr, serat 6 gr, kalsium $285 \mathrm{gr}$, fosfor $1,1 \mathrm{mg}$.

Tepung ikan lele tinggi akan kandungan protein. Substitusi Tepung ikan lele dan Tepung kepala ikan lele akan meningkatkan protein dan kalsium dalam produk cookies. Akan tetapi, penggunaan tepung ikan lele memiliki kelemahan yakni aroma dan rasa amis. Tujuan penelitian ini adalah untuk melihat efek substitusi tepung ikan lele terhadap mutu organoleptik. dan nilai gizi Gluten Free and Casein Free cookies untuk anak dengan Autism Spectrum Disorder (ASD).

\section{METODE}

Penelitian ini merupakan eksperimental murni dengan desain Rancangan Acak Lengkap (RAL). Terdapat variasi 4 formula substitusi tepung ikan lele dan tepung kepala ikan lele pada pembuatan cookies bebas gluten dan bebas kasein dengan tiga kali pengulangan. Penelitian dilakukan pada bulan Juli 2017.

Pembuatan cookies dilakukan di Laboratorium Pengolahan Gizi Fakultas Kesehatan Masyarakat Universitas Airlangga 
Surabaya, sedangkan uji organoleptik dilakukan di Pusat Layanan Autis Sidoarjo, dan uji kadar protein dan kalsium di Balai Besar Laboratorium Kesehatan Daerah Surabaya.

Tabel 1. Formula Cookies Bebas Gluten dan Kasein Tersubstitusi Tepung Ikan Lele

\begin{tabular}{lcccc}
\hline \multirow{2}{*}{ Komposisi (\%) } & \multicolumn{4}{c}{ Formula } \\
\cline { 2 - 5 } & F0 & F2 & F3 & F5 \\
\hline Tepung beras & 36 & 32 & 28 & 26 \\
Tepung ikan & 0 & 2 & 4 & 6 \\
Tepung kepala & 0 & 2 & 4 & 4 \\
Maizena & 8 & 8 & 8 & 8 \\
Tapioka & 8 & 8 & 8 & 8 \\
Gula & 20 & 20 & 20 & 20 \\
Margarin & 21 & 21 & 21 & 21 \\
Kuning Telur & 6 & 6 & 6 & 6 \\
Vanila & 1 & 1 & 1 & 1 \\
\hline \multicolumn{1}{c}{ Total } & 100 & 100 & 100 & 100 \\
\hline \multicolumn{1}{c}{} & & & &
\end{tabular}

Panelis pada penelitian ini adalah panelis tidak terlatih, yakni orang tua dan anak dengan ASD di Pusat Layanan Autis Sidoarjo sebanyak 20 orang. Persentase substitusi tepung ikan lele yang ditambahkan didasarkan pada syarat mutu SNI cookies, yakni minimal 5 gram protein per 100 gram finished product. Persentase formulasi substitusi juga didasarkan pada penelitian pendahuluan yang dilakukan peneliti, bahwa substitusi lebih dari 10\% (tepung ikan dan tepung tulang ikan) memiliki daya terima yang sangat rendah dan kurang disukai dari aspek rasa dan aroma.

Penelitian lain tentang substitusi tepung ikan pada produk cookies menyatakan substitusi optimal terhadap formulasi resep antara 5-20\% dari total resep (Mervina et al., 2012; dan Pratama et al., 2014). Tepung badan ikan lele dan tepung tulang ikan lele disubstitusikan terhadap tepung beras. Hal ini dikarenakan kedua bahan tersebut (tepung beras dan tepung ikan) memiliki pati yang rendah, sehingga karakteristiknya hampir sama tetapi tepung ikan lele memiliki kandungan protein yang lebih tinggi.

Tahap pertama proses pembuatan cookies adalah menyangrai tepung yang akan digunakan. Tepung beras, tepung tapioka, tepung maizena, di campur dan diayak lalu di sangrai selama 5 menit kemudian ditunggu hingga dingin. Penyangraian tepung bertujuan untuk mengurangi kadar air dan memperbaiki tekstur cookies. Langkah berikutnya dilakukan pencampuran tepung yang sudah dingin, gula halus, margarin (dingin, dengan suhu $5^{\circ} \mathrm{C}$ ), kuning telur, dan vanila menggunakan mixer (selama 30 detik). Setelah adonan tercampur rata, adonan dicetak dengan ketebalan $0,5 \mathrm{~cm}$. Cookies kemudian diletakkan di loyang yang telah diolesi dengan margarin. Cookies kemudian di panggang dalam oven pada suhu $165^{\circ} \mathrm{C}$ selama 25 menit. Bagian atas dan bawah oven memiliki suhu yang sama.

$$
\text { Penilaian yang dilakukan pada }
$$
penelitian ini berupa penilaian daya terima dan penghitungan kadar protein serta kalsium. Penilaian daya terima (warna, aroma, tekstur, dan rasa) oleh panelis tak terlatih menggunakan angket uji kesukaan, sedangkan penghitungan kadar protein dan kalsium dihitung berdasarkan DKBM dan uji kandungan zat gizi.

Hasil uji daya terima diolah dan dianalisa untuk mengetahui daya terima tinggi. Uji Kruskal Wallis $(\alpha=0,05)$ digunakan untuk mengetahui perbedaan daya terima cookies dengan substitusi tepung badan ikan lele dan 
tepung kepala ikan lele. Uji lanjut Mann Whitney $(\alpha=0,05)$ digunakan untuk mengetahui signifikansi perbedaan tiap formula. Formula terbaik dari segi daya terima dan nilai gizi perhitungan, selanjutnya akan diuji kadar protein dan kalsiumnya. Kadar protein diuji dengan metode kjehdal, sedangkan kadar kalsium diuji dengan metode Absorbsion Atomic Spectrofotometer (AAS) pada panjang gelombang 422,7 $\mathrm{nm}$.

Penelitian ini telah mendapat persetujuan Komisi Etik Penelitian Kesehatan, Fakultas Kesehatan Masyarakat, Universitas Airlangga, Surabaya (No:259-KEPK).

\section{HASIL DAN PEMBAHASAN}

Tabel 2 menunjukkan bahwa dari aspek tekstur, penilaian tertinggi panelis adalah pada F5. Panelis lebih menyukai F5 dibandingkan F0, cookies tanpa penambahan tepung kepala ikan cenderung memiliki tekstur yang mudah rapuh, substitusi $4 \%$ tepung kepala ikan pada cookies dapat meningkatkan kesukaan tekstur panelis. Kandungan mineral kalsium pada Tepung tulang ikan yang disubstitusikan, memperbaiki tekstur cookies.

Tabel 2. Distribusi Nilai Mean Rank dan Uji Perbedaan Tingkat Kesukaan Tekstur, Aroma, Rasa, dan Warna

\begin{tabular}{cccccc}
\hline \multirow{2}{*}{$\begin{array}{c}\text { Organolep- } \\
\text { tik }\end{array}$} & \multicolumn{5}{c}{ Mean rank } \\
\cline { 2 - 5 } & F0 & F2 & F3 & F5 & value \\
\hline Tekstur & 49,2 & 44,1 & 52,8 & 55,9 & 0,553 \\
Aroma & 47,3 & 47,1 & 51,1 & 56,5 & 0,029 \\
Rasa & 42,1 & 49,0 & 52,8 & 58,0 & 0,033 \\
Warna & 52,1 & 50,1 & 48,1 & 51, & 0,282 \\
\hline
\end{tabular}

Aroma yang dihasilkan cookies pada formula kontrol (F0) didominasi oleh aroma gurih margarin dan vanila, sedangkan aroma pada F2 (2\%:2\%); F3 (4\%:4\%); dan F5 (6\%:4\%) merupakan aroma khas dari gabungan vanila dan tepung ikan (amis). Hasil uji organoleptik panelis tidak terlatih (orang tua anak ASD) terhadap aroma cookies menunjukkan bahwa F5 memiliki aroma yang paling disukai panelis.

Hal ini sesuai dengan penelitian, Mervina, et al (2012) menyebutkan bahwa tepung ikan lele memiliki aroma yang khas, sehingga ketika ditambahkan pada biskuit akan merubah aroma khas dari biskuit. Pratama (2014) juga menyebutkan, penambahan tepung ikan pada biskuit menyebabkan tekstur biskuit lebih rapuh dibandingkan dengan biskuit tanpa modifikasi.

Rasa merupakan salah satu unsur penting dalam penilaian tingkat kesukaan, rasa yang enak akan dapat diterima oleh panelis/konsumen. Pada formula kontrol (F0) menghasilkan rasa vanila. Pada F2 (2\%:2\%); F3 (4\%:4\%); dan F5 (6\%:4\%) rasa yang terbentuk merupakan gabungan dari rasa vanila, rasa manis, serta rasa gurih dari tepung ikan lele dan tepung tulang ikan lele.

Tabel 2 juga memperlihatkan bahwa rasa cookies yang mendapatkan penilaian paling tinggi adalah pada fomula F5 dengan nilai mean rank 58,00. Hal ini bermakna panelis lebih menyukai kombinasi rasa vanila dan tepung ikan daripada rasa vanila saja. 
Warna cookies yang dihasilkan yakni tidak ada beda yang signifikan antara warna pada F0, F2 (2\%:2\%); F3 (4\%:4\%); dan F5 (6\%:4\%). Pada F0 warna yang dihasilkan kuning cerah, sedangkan pada cookies dengan formulasi warna yang dihasilkan kuning kecoklatan (dengan bintik halus berwarna coklat berasal dari tepung ikan).

Hasil uji organoleptik pada panelis tidak terlatih (orang tua anak ASD) terhadap warna cookies ditampilkan pada Tabel 2. Berdasarkan nilai mean rank aroma, diketahui bahwa panelis lebih menyukai F0 $(52,06)$ dibandingkan dengan formula yang lain.

Mahmudah (2013) juga menyebutkan bahwa penambahan tepung ikan pada biskuit akan mempengaruhi rasa dari biskuit, penambahan bahan dengan rasa kuat (perasa atau rempah) dapat digunakan sebagai alternatif dalam mengurangi rasa yang kuat pada biskuit yang dimodifikasi tepung ikan lele.

Gambar 1 memperlihatkan bahwa plot pada formula F5 mengarah paling luar. Hal ini menunjukkan bahwa segi tekstur, rasa, aroma, dan warna, panelis lebih menyukai F5 dibandingkan formula lainnya.

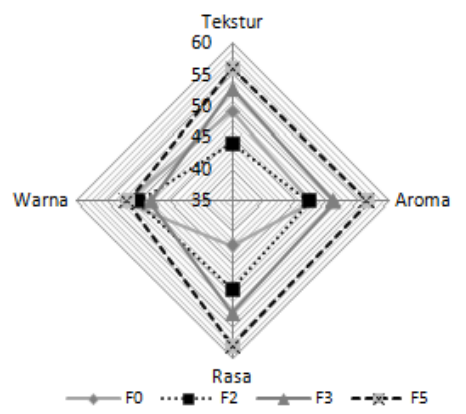

Gambar 1. Daya Terima Panelis
Hasil uji daya terima diolah dan dianalisa untuk mengetahui perbedan dari masing-masing formula. Hasil analisis statistik dengan uji Kruskal Wallis $(\alpha=0,05)$, menunjukkan bahwa substitusi tepung badan dan tepung tulang ikan lele memberikan pengaruh yang signifikan terhadap tingkat kesukaan pada aspek rasa dan aroma ( $p=0,033$; dan $p=0,024)$. Hasil uji Mann Whitney memperlihatkan adanya perbedaan yang nyata pada aspek rasa antara F0, F3, dan F5, sedangkan pada aspek aroma perbedaan nyata yakni pada F0 dan F5.

Sifat kelarutan air tepung ikan dan tepung beras hampir sama, dimana kedua produk ini rendah akan kandungan pati (Mervina, et al, 2012). Karakteristik tepung ikan yang mensubstitusi tepung beras tidak berpengaruh signifikan terhadap tekstur cookies di semua formulasi.

Substitusi tepung badan dan tulang ikan lele memberikan pengaruh bermakna pada perubahan rasa dan aroma cookies, namun hal ini tidak menurunkan daya terima cookies bebas gluten dan kasein yang tersubstitusi. Pada produk ini kandungan protein per 100 gram cookies adalah 9,56 gram, dimana kandungan ini sudah menjadi kriteria SNI untuk cookies (sekurang-kurangnya $5 \mathrm{~g}$ per $100 \mathrm{~g}$ produk). Faktor daya terima dan tingginya kandungan protein dalam produk ini menunjukkan produk cookies sengan substitusi ikan lele tepat digunakan sebagai alternatif snack sehat untuk anak ASD. 
Tabel 5. Hasil Uji Laboratorium Kandungan Gizi Protein dan Kalsium per 100 Gram cookies

\begin{tabular}{lcc}
\multicolumn{1}{c}{ Keterangan } & Protein $(\mathbf{g})$ & Kalsium $(\mathbf{m g})$ \\
\hline Hasil Uji Laboratorium & 6,8 & 247,5 \\
Perhitungan DKBM & 9,5 & 250,4 \\
Selisih & 2,7 & 2,9 \\
\hline
\end{tabular}

Berdasarkan tabel 5 terdapat perbedaan kandungan zat gizi khususnya protein. Penurunan kadar protein dari perhitungan DKBM terjadi dikarenakan teknologi yang digunakan pada proses produksi cookies. Terdapat 2 kali proses yakni, penyangraian tepung ikan lele selama 3 menit dan pemanggangan cookies dengan suhu $165^{\circ} \mathrm{C}$ selama 25 menit.

Pemanasan menyebabkan proses denaturasi protein, yang berarti perubahan terhadap struktur molekul protein tanpa terjadi pemecahan ikatan-ikatan kovalen (Palupi, 2007). Akan tetapi, pemanasan pada proses produksi dapat meningkatkan daya cerna protein dan daya simpan protein (Sundari et al., 2015).

Pengolahan pangan berbasis bahan pangan lokal seperti ikan lele dapat meningkatkan nilai guna bahan pangan tersebut. Selain itu nilai gizi yang terdapat pada pangan yang dibuat dengan bahan pangan lokal menjadi semakin baik.

\section{KESIMPULAN DAN SARAN}

Substitusi tepung badan dan tepung tulang ikan lele memberikan pengaruh yang signifikan terhadap sifat organoleptik (rasa dan aroma), sehingga terdapat perbedaan yang nyata terhadap rasa dan aroma antara formula F0, F3 dan F5. Hasil uji organoleptik terhadap warna, aroma, tekstur, dan rasa cookies F2 (2\%: 2\%); F3 (4\%:
4\%); dan F5 (6\%: 4\%) menunjukkan formula yang paling disukai adalah F5.

Kadar protein dan kalsium per $100 \mathrm{~g}$ cookies formula F5 mengandung protein 8 gram, dan kandungan kalsium 247,5 mg . Dalam 100 gram cookies dapat memenuhi 19\% kecukupan protein dan 24,8\% kecukupan kalsium anak usia 4-6 tahun berdasarkan Angka Kecukupan Gizi 2013.

Cookies dengan substitusi tepung badan dan tepung tulang ikan lele dapat dijadikan alternatif jajanan anak ASD, dengan komposisi bahan gluten, bebas kasein, bebas bahan pengembang, cukup kalsium dan protein.

\section{DAFTAR PUSTAKA}

Amalia, R., \& Dieny, F. (2014). Perbedaan kepadatan tulang antara penderita autis dan tidak autis. Journal of Nutrition College, 3(2), 40-47, https://doi.org/10.14710/jnc.v3i2.5439

Burkle, K. A., Edward, R. A., Fleet, G. H., \& Wotton, M. (2007). Ilmu pangan. Diterjemahkan oleh: Purnomo $\mathrm{H}$, Adiono. Jakarta: UI Press.

Center for Disease Control and Prevention [CDC]. (2014). Community Report and Developmental Disabilities Monitoring (ADDM) Network. United States: Centers for Disease Control and Prevention (CDC) Retrieved from $<$ https://www.cdc .gov/ncbddd/autism/states/comm_report_ autism_2014.pdf>

Cieślińska A., Sienkiewicz-Szłapka, E., Wasilewska, J., Fiedorowicz, E., Chwala, B., Moszyńska-Dumara, M., ... Kostyra, E. (2015). Influence of candidate 
polymorphisms on the dipeptdyl peptidase $I V$ and $\mu$-opioid receptor genes expression in aspect of the $\beta$-casomorphin-7 modulation functions in autism. Peptides Jornal. $65.6-11.6$ doi: 10.1016/j.peptides.2014.11.012

Departemen Kesehatan Republik Indonesia. (2012). Profil kesehatan Indonesia 2011. Jakarta: Depkes RI.

Ekhlaspour, L., Mondesir, D., Lautsch, N., Balliro, C., Hillard, M., Magyar, K., ... Russell, S.J (2017). Comparative accuracy of 17 point-of-care glucose meters. J Diabetes Sci Technol. 11(3):558-566. doi: $10.1177 / 1932296816672237$

Faridah, A., Pada, K.S., Yulastri, A., \& Yusuf, L. (2008). Patiseri Jilid 3 untuk SMK. Jakarta: Direktorat Pembinaan Seklah Menengahh Kejuruan, Departemen Pendidikan Nasional.

Lázaro C. P, Pondé M. P., dan Rodrigues L. E. A.(2016). Opioid peptides and gastrointestinal symptoms in autism spestrum disorder. Revista Brasileira de Psiquatria, 38. 243-246. Retrieved from $<$ http://dx.doi.org/10.1590/1516-44462015-1777>

Lean, M. E. J. (2013). Ilmu pangan, gizi, dan Kesehatan. Diterjemahkan oleh: Nata Nilamsari dan Astri Fajriyah. Yogyakarta: Pustaka Pelajar

Mahmudah S. (2013). Pengaruh substitusi tepung ikan lele terhadap kadar kalisum, kekerasan dan daya terima biskuit (Skripsi), Universitas Muhamadiyah.

Megawati. (2011). Studi pola asuh gizi dan pertumbuhan fizik anak autis di yayasan dan di rumah sakit (Skripsi), Universitas Ailangga, Surabaya.

Mervina, Kusharto, C. M., \& Marliyati, S. A. (2012). Formulasi biskuit dengan substitusi tepung ikan lele dumbo (Clarias gariepinus) dan Isolat Protein Kedelai (Glycine max) sebagai makanan potensial untuk balita gizi kurang. Jurnal Teknologi dan Industri Pangan, 23. 9-16. Retrieved from <http://journal.ipb. ac.id/index.php/jtip/article/view/5287/422 9>

Mulloy, A., Lang, R., O'Reilly, M., Sifagoos, J., Lancioni, G., \& Rispoli, M. (2009). Gluten-free and casein-free diets in the treatment of autism spectrum disorders: A systematic review. Research in Autism Spectrum Disorders. Retrieved from <doi:10.1016/j.rasd.2009.10.008.>

Neumeyer, A. M., O’Rourke, J. A., Massa. A., Lee, H., Lawson, E. A., McDougle, C. J., \& Misra, M. (2015). Brief report: Bone fractures in children and adults with autism spectrum disorders. Journal of Autism and Developmental Disorders, 45(3), 881-887. doi: 10.1007/s10803014-2228-1.

Palupi, S. (2007). Hubungan tingkat pendidikan orang tua dengan pola hidup sehat anak. Jurnal Ilmiah Pendidikan, 26(2), 309326, doi: https://doi.org/10.21831/cp.v2i2.8558

Persatuan Ahli Gizi Indonesia [Persagi]. (2009). Tabel komposisi pangan Indonesia. Jakarta: Media Elex Komputindo.

Pratama, R. I., Rostini, I., dan Liviawaty E. (2014). Karakteristik biskuit dengan penambahan tepung tulang ikan jangilus (Istiophirus sp.) (Skripsi). Universitas Padjadjaran, Bandung, Indonesia.

Postorino, V., Sanges V., Giovagnoli G., Fatta L. M.., Peppo L.D., Armando M., ... Mazzone L.. (2015). Clinical differences in children with autism spectrum disorder with and without food selectivity. Research report, Research in Autism Spectrum Disorder, 92, 126-132. Retrieved from $<$ http://dx.doi.org/10.1016/j.appet.2015.0 5.016>

Sundari, D., Almasyhuri., \& Lamid, A. (2015). Pengaruh proses pemasakan terhadap komposisi zat gizi bahan pangan sumber protein. Media Litbangkes, 25(4), 235242. Retrieved from https://media.neliti.com/media/publicatio ns/20747-ID-pengaruh-prosespemasakan-terhadap-komposisi-zat-gizibahan-pangan-sumber-protei.pdf

Tejasari. (2005). Nilai gizi pangan. Yogyakarta: Graha Ilmu

Trivedi, M. S., Shah, J. S., Al-Mughairy, S., Hodgson, N. W., Simms, B., Trooskens G. A., ... Deth R. C. (2014). Foodderived opioid peptides inhibit cystein uptake with redox ang epigenetics consequances. Journal of Nutritional Biochemistry, 25(10), 1011-1018. doi: 10.1016/j.jnutbio.2014.05.004 
Truswell, A. S, \& Mann, J. (2012). Essentials oh human nutrition (4th ed.). England: Oxford University Pers.
Winarno, F. G. (2013). Autisme dan peran pangan. Jakarta : Gramedia Pustaka 